\title{
Detection of antibodies to Mycobacterium tuberculosis plasma membrane antigen by enzyme-linked immunosorbent assay
}

\section{E. KRAMBOVITIS}

\author{
Department of Diagnostics Research and Development, Wellcome Research Laboratories, Beckenham, \\ Kent BR3 $3 B S$
}

\begin{abstract}
Summary. Antibody activity against Mycobacterium tuberculosis of sera from an area with a high prevalence of tuberculosis was measured by enzyme-linked immunosorbent assay (ELISA) with a plasma-membrane extract from $M$. tuberculosis strain $\mathrm{H}_{37} \mathrm{RV}$. All sera from relapsed tuberculosis patients and $82.5 \%$ of sera from new untreated cases gave positive results. The seronegative group of tuberculosis patients gave positive results by direct microscopy and culture. No clear correlation between antibody and delayed hypersensitivity or extent of disease was observed. Chemotherapy was associated with a higher antibody response. Specificity of the test with healthy control subjects from the high prevalence area was $85 \%$. Negative results were obtained with 145 sera from presumed healthy European subjects and with seven sera from BCG-vaccinated subjects.
\end{abstract}

\section{Introduction}

Availability of new, more sensitive antibody assays, particularly enzyme immunoassays, has stimulated a resurgence of interest in the serology of tuberculosis. Several antigens have been evaluated for their serodiagnostic potential in detecting circulating antibodies by enzyme-linked immunosorbent assay (ELISA) (Nassau et al., 1976; Grange et al., 1980; Reggiardo et al., 1980; Daniel et al., 1981; Zeiss et al., 1982; Benjamin and Daniel, 1982; Stroebel et al., 1982; Benjamin et al., 1984). The sensitivities and specificities of these assays vary considerably and interpretation of the reported results is difficult because of limited clinical information.

Recently, antibodies raised against a plasmamembrane antigen from Mycobacterium tuberculosis were used to detect antigen in the cerebrospinal fluid of tuberculous meningitis patients (Krambovitis et al., 1984). In the present study, the same antigen was used to develop an ELISA technique to measure antibody responses in tuberculosis. The activity of specific antibody in sera from new and relapsed cases was correlated with extent of disease, delayed hypersensitivity and duration of chemotherapy. The effect of $B C G$ vaccination on the antibody activity and results obtained with sera from healthy subjects are also presented.

Received 22 Apr. 1985; accepted 23 Aug. 1985.

\section{Materials and methods}

\section{Extraction of antigen.}

M. tuberculosis $\mathrm{H}_{37} \mathrm{RV}$ (NCTC 7416) was grown in Sauton's synthetic medium at $37^{\circ} \mathrm{C}$ for 4 weeks and killed by the addition of phenol $5 \% \mathrm{w} / \mathrm{v}$. Phenolised cells were washed three times in $66 \mathrm{~mm}$ sodium phosphate buffer $\mathrm{pH}$ 7.4 (PB) and extracted with sodium dodecyl sulphate $1 \%$ in $\mathrm{PB}$ at $80^{\circ} \mathrm{C}$ for $1 \mathrm{~h}$. After centrifugation at $10000 \mathrm{~g}$ for 1 $\mathrm{h}$ the supernate was filtered through a $0 \cdot 22-\mu \mathrm{m}$ pore-size membrane (Millipore) and chromatographed with ion retardation resin AG 11 A8 (Bio-Rad Laboratories) to remove excess detergent (Kapp and Vinogradov, 1978).

\section{Enzyme-linked immunosorbent assay.}

Flat-bottomed microtitration plates (Titertek, Flow Laboratories) were sensitised with a solution of antigen $30-50 \mu \mathrm{g} / \mathrm{ml}$ in $\mathrm{PB}$ at $37^{\circ} \mathrm{C}$ for $30 \mathrm{~min}$. Excess antigen was washed off with saline containing Tween 20 (Koch-Light Laboratories) $0.05 \%$ (TS) for $10 \mathrm{~min}$. Test sera were diluted 1 in 40 in PB containing 1 mm dithiothreitol, $1 \mathrm{~mm}$ EDTA and Tween $200.05 \%$, and $200-\mu$ l volumes were added to the sensitised wells in quadruplicate. The plate was incubated at room temperature for $1 \mathrm{~h}$ after which the wells were washed for $10 \mathrm{~min}$ with TS. Peroxidase labelled sheep anti-human IgG (Duncan, et al., 1983) was diluted to working strength with PB containing bovine serum albumin $0.5 \%$ and Tween $200.05 \%$, and $200 \mu \mathrm{l}$ added to each well. The plate was incubated at room temperature for $1 \mathrm{~h}$ and washed with eight changes of TS during a 
period of $15 \mathrm{~min}$. The substrate-chromogen solution was prepared just before use by dissolving 5-aminosalicylic acid (Cambrian Chemicals) previously purified and recrystallised (Ellens and Gielkens, 1980) $0.8 \mathrm{mg} / \mathrm{ml}$ in $0.05 \mathrm{M}$ citrate buffer, $p \mathrm{H} 6.5$, containing $4.5 \mathrm{~mm}$ hydrogen peroxide. The substrate-chromogen was added and incubated for $30 \mathrm{~min}$ at room temperature. The reaction was stopped by adding $25 \mu \mathrm{l}$ of $1 \mathrm{M}$ sodium hydroxide to each well and the optical density (OD) was measured at $450 \mathrm{~nm}$ (Titertek Multiskan, Flow Laboratories). The results were expressed as "antibody activity". This was the mean OD of each test serum multiplied by 100 . To minimise the influence of day-to-day fluctuation of OD on the results, a standard serum was tested alongside the test sera on the same plate and the OD readings were adjusted accordingly. Antibody activity $>50$ was considered to represent a positive result.

\section{Patients}

Sera and case histories from 100 bacteriologically proven tuberculosis patients and 41 "healthy" subjects were collected at the T.B. Research Institute, Pretoria, South Africa during a period of 2 months. The tuberculosis group consisted of 48 African and 52 Asian patients, of whom 87 were male and 13 were female; their mean $( \pm S D)$ age was $40( \pm 13)$. The control group consisted entirely of African subjects, of whom $35(85 \%)$ were male and $6(15 \%)$ female; their mean age was $33( \pm 13)$. The sera were tested blind. Sera from a group of five tuberculosis negative adult subjects were studied before BCG vaccination and again 2 months after vaccination. Two other subjects were followed for 2 years after vaccination.

Control sera were collected from 95 healthy company employees in Britain and 50 sera were obtained from the National Blood Transfusion Service (Britain). No medical information was obtained on these samples; all were presumed to be from healthy individuals.

\section{Results}

\section{New and relapsed infections}

All sera with the exception of one from a case of lymphatic tuberculosis were from patients with pulmonary tuberculosis, $19 \%$ of whom had relapsed infections. Sera from $92.5 \%$ of the new cases and from all relapsed cases gave a positive antibody test (fig. 1). However, there was no difference in mean antibody activity between sera from the new cases $(235 \pm 140)$ and from relapsed cases $(255 \pm 133)$.

\section{Effect of chemotherapy}

The mean antibody activity of the 11 sera from untreated tuberculosis patients was $137( \pm 80)$; $82.5 \%$ of such sera gave positive results (table I). Of the patients studied, 89 were on anti-tuberculous

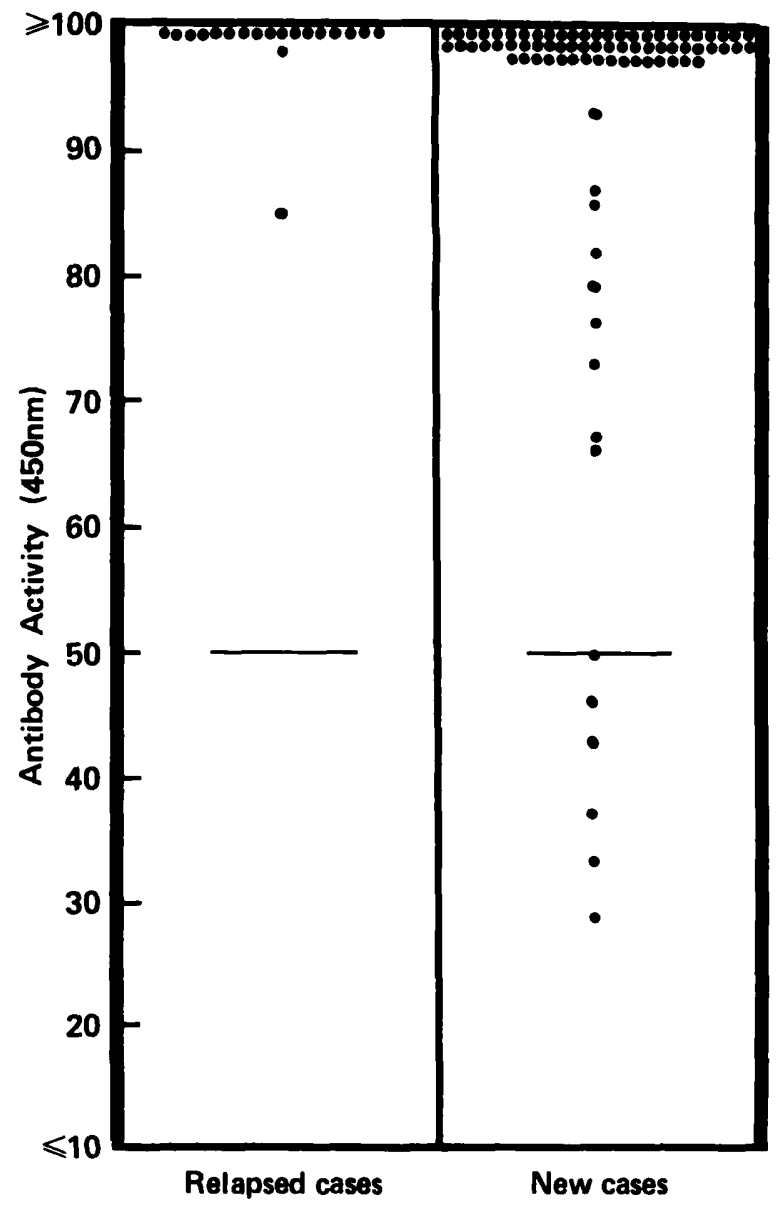

Fig. 1. Distribution of serum antibody activity in relapsed and new pulmonary tuberculosis patients (bar represents the cut-off point). Each point represents one patient's serum sample.

therapy consisting mainly of isoniazid, streptomycin and pyrazinamide, supplemented with rifampicin and ethambutol, and 85 had responded well to treatment; they had gained, on average, $3 \mathrm{~kg} / \mathrm{month}$ in weight and their chest radiographs had improved considerably. The proportion of positive tests and the mean antibody activity increased considerably during the first 3 months of therapy (table I). The four patients who were not responding to therapy had high antibody activity.

\section{Extent of disease}

Antibody activity was assessed in relation to severity of disease classified, from the extent of cavitation, as minimal, moderately advanced and far-advanced. No marked differences were noted between the three groups (table II), although the trend was towards higher antibody activities in sera 
Table I. Effect of chemotherapy on $M$. tuberculosis antibody

\begin{tabular}{cc|cc}
\hline $\begin{array}{c}\text { Duration of } \\
\text { therapy } \\
\text { (months) }\end{array}$ & $\begin{array}{c}\text { Number } \\
\text { of } \\
\text { sera }\end{array}$ & $\begin{array}{c}\text { Mean antibody activity (SD) } \\
\text { and range }\end{array}$ & $\begin{array}{c}\text { Percentage of sera } \\
\text { that gave } \\
\text { positive results }\end{array}$ \\
\hline 0 & 11 & $137(80)$ & $82 \cdot 5$ \\
$29-280$ & $217(133)$ \\
$37-560$ & $91 \cdot 5$ \\
1 & 24 & $241(142)$ & $96 \cdot 5$ \\
2 & 28 & $33-450$ & $95 \cdot 0$ \\
3 & 23 & $93-432$ & $94 \cdot 0$ \\
$>3$ & 14 & $452(123)$ & \\
\hline
\end{tabular}

SD $=$ Standard Deviation

Table II. Comparison of antibody activity with severity of disease

\begin{tabular}{cc|ccc}
\hline & & \multicolumn{3}{|c}{ Mean antibody activity $( \pm \mathrm{SD})$ and range in sera from } \\
patients with
\end{tabular}

* Numbers of sera tested in each category are given in parentheses.

from far-advanced cases, particularly before, and during the early stages of, treatment.

\section{Delayed hypersensitivity}

A series of 78 patients, mostly with minimal and moderately advanced pulmonary disease were tuberculin tested for delayed hypersensitivity by the Heaf test. Skin reactions were classified from anergic (grade 0 ) to strongly positive (grade IV). There were no marked differences in antibody activity between the groups (table III) although the group with strong skin reactions (grade IV) gave lower antibody results. Five sera were from patients before treatment; four of these patients had grade I reactions and their sera gave a mean antibody activity of 150 (SD 90) and the fifth had a grade II reaction and an antibody activity of 112 .

\section{Control sera}

The mean antibody activity of 145 sera collected mainly from European subjects was 23 (SD 8.5). None of these exceeded the cut-off point though three samples were borderline (fig. 2). Samples were also collected at the hospital from 41 "healthy" African volunteers. Distribution of the antibody activity of individual sera is shown in fig. 3 . Specificity of the test with this control group was $85 \%$. 
Table III. Comparison of the antibody test results with delayed hypersensitivity

\begin{tabular}{cc|cc}
\hline $\begin{array}{c}\text { Skin test } \\
\text { grade }\end{array}$ & $\begin{array}{c}\text { Number } \\
\text { of } \\
\text { sera }\end{array}$ & $\begin{array}{c}\text { Mean antibody activity } \\
\text { (SD) and range }\end{array}$ & $\begin{array}{c}\text { Percentage of } \\
\text { sera that gave } \\
\text { positive } \\
\text { results }\end{array}$ \\
\hline 0 & 4 & $\begin{array}{c}308(57) \\
238-380\end{array}$ & 100 \\
I & 32 & $\begin{array}{c}264(137) \\
29-560\end{array}$ & 94 \\
II & 15 & $\begin{array}{c}270(121) \\
43-432 \\
266(139) \\
37-450 \\
141(140) \\
33-400\end{array}$ \\
III & 22 & 5 & $95 \cdot 6$ \\
IV & 5 & 60 \\
\hline
\end{tabular}

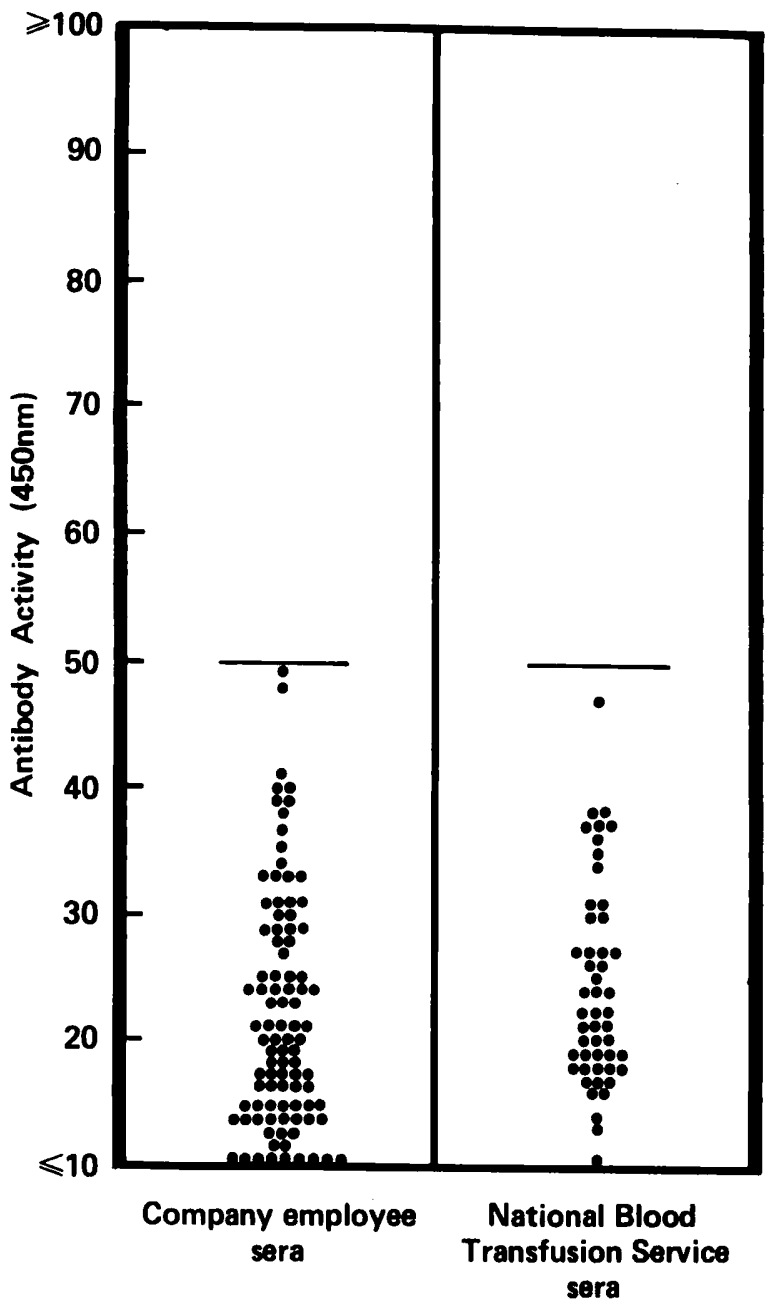

Fig. 2. Distribution of serum antibody activity in healthy European subjects (bar represents the cut-off point). Each point represents one subject's serum.

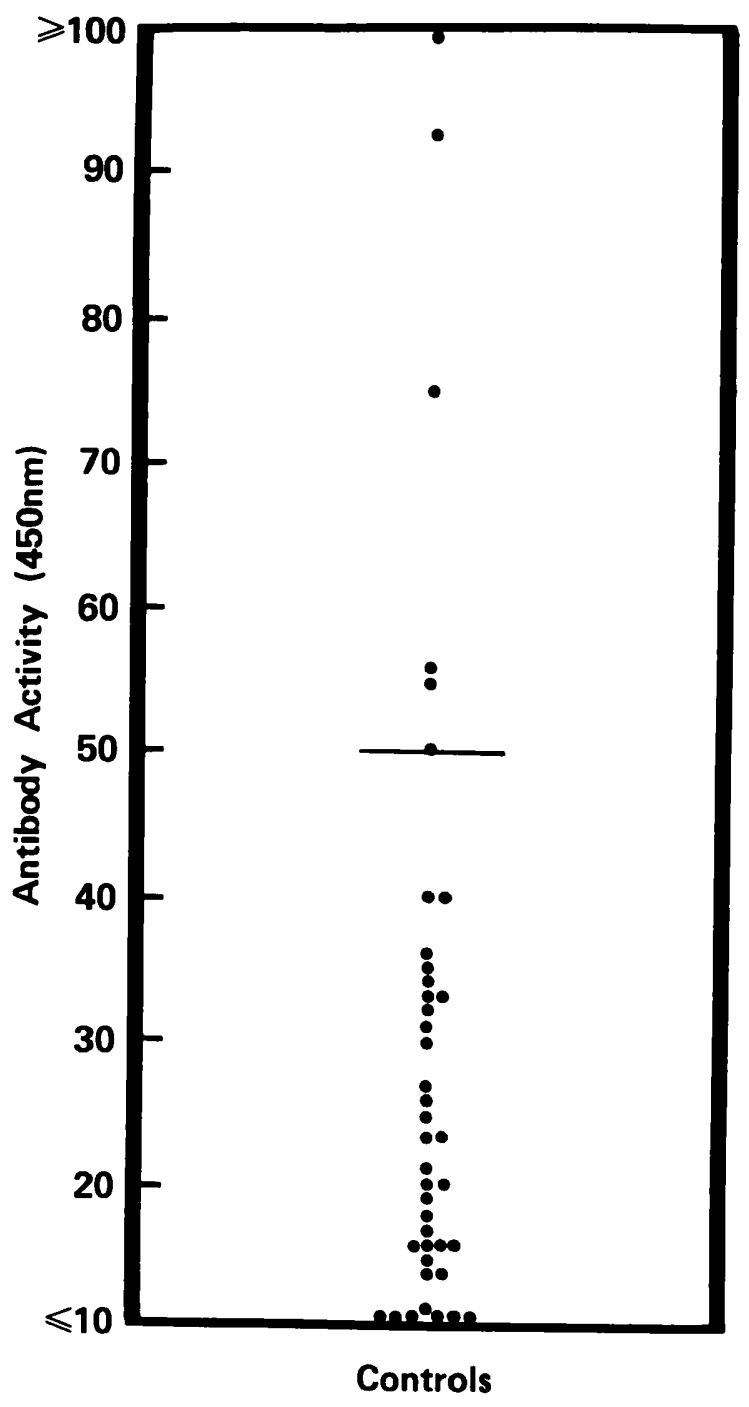

Fig. 3. Distribution of serum antibody activity in healthy subjects living in a high prevalence area (bar represents the cutoff point). Each point represents one subject's serum.

\section{Effect of $B C G$ vaccination}

Sera from a selected group of five healthy adults with tuberculin-negative skin tests were collected before BCG vaccination and 2 months after vaccination. The results showed no marked changes in their antibody activities (fig. 4). Sequential samples from two other individuals also showed no significant changes in antibody activity during 2 years after BCG vaccination (fig. 5).

\section{Discussion}

It is generally accepted that infection with $M$. tuberculosis often induces a humoral response 


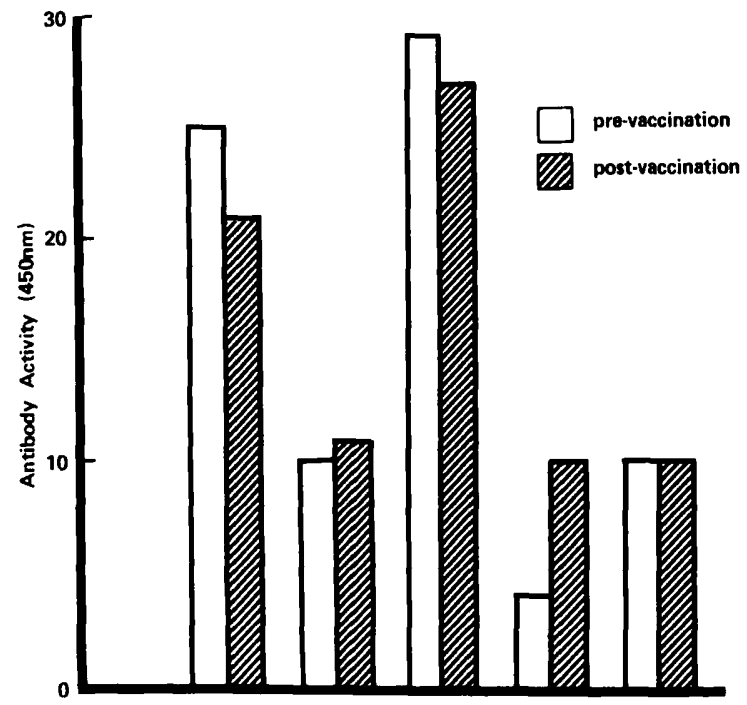

Fig. 4. Antibody activity of sera from five subjects before and after vaccination with $M$. bovis strain BCG.

which can be detected and measured with mycobacterial antigens (Grange, 1984). The role of these antibodies is not clear, particularly as there is no apparent involvement in the expression of acquired immunity (Suter, 1956) nor in the process of phagocytosis (Mackaness, 1954; Reggiardo and
Middlebrook, 1974). A better understanding of the humoral mechanism, particularly in relation to other clinical manifestations, may lead to a more rational design of diagnostic tests based, at least partially, on the detection of immune responses. Many recent serological studies utilised enzyme immunoassay techniques because of the sensitivity and relative simplicity of such assays. In the present study an ELISA based on a heat-stable plasmamembrane antigen was developed to compare immune responses with other parameters of clinical significance.

In ELISA systems for measuring circulating antibodies, results have been expressed in three main ways: end-point antibody titre, untransformed $O D$ readings at a single sample dilution, and antibody-activity units in relation to reference sera. Single OD readings are inconsistent because of systematic and random variability and titrations suffer from poor reliability and relatively higher reagent costs (Malvano et al., 1982). The third option was preferred for our studies. A reference serum selected for activity close to the cut-off point which would reflect linearly any between-run variation of test samples was introduced to the assay. "Antibody activity" was derived by dividing the OD value of the test sample by the OD value of the reference serum and multiplying by 40 (during

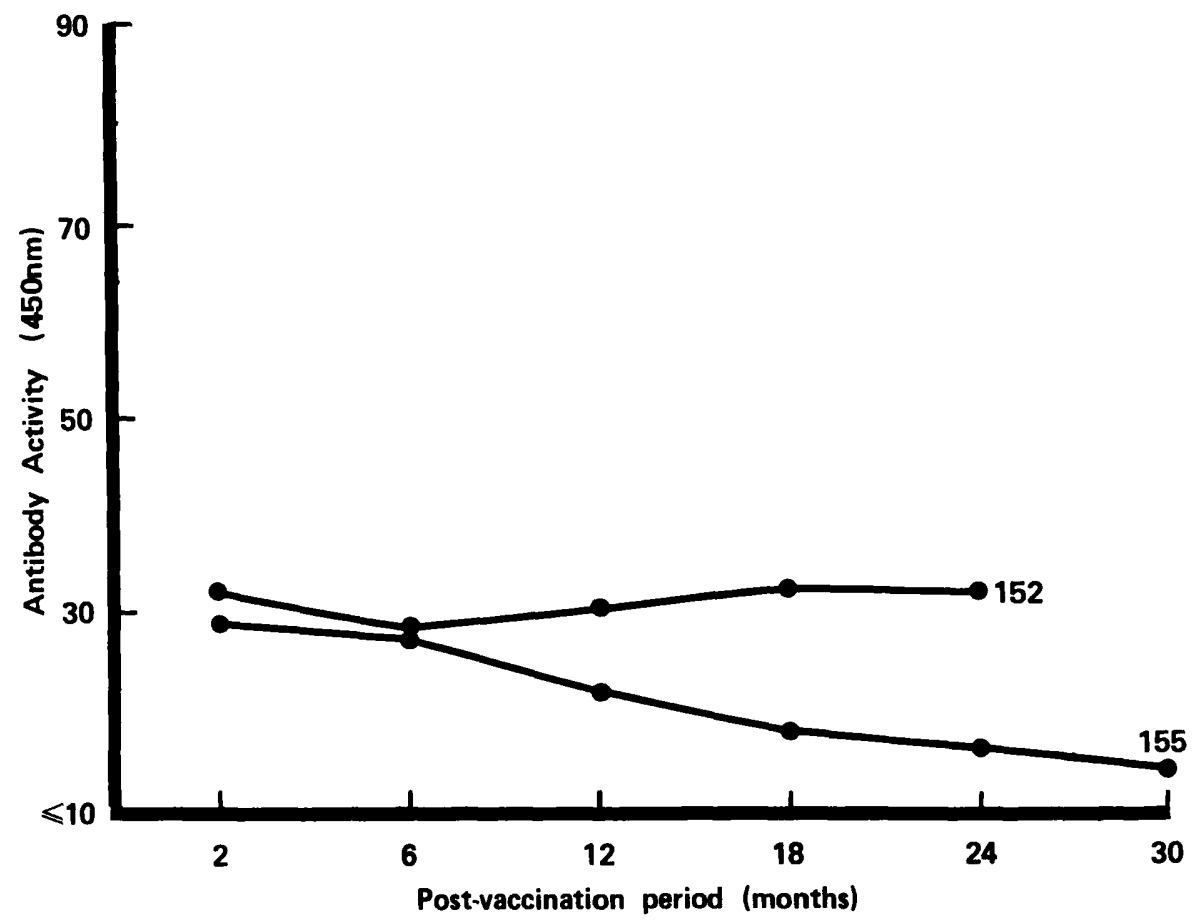

Fig. 5. Antibody activity of sequential serum samples from two individuals vaccinated with $M$. bovis strain BCG. 
initial experiments the OD readings of the reference serum were 0.4). A similar reference system was used by Kalish et al. (1983) to measure circulating antibodies to purified protein derivative.

In the early stages of the assay's development, specific serum IgG, IgM and IgA antibodies were measured. The most pronounced specific antibody which correlated with active disease was IgG which is in agreement with previous reports (Grange et al., 1980; Benjamin and Daniel, 1982; Zeiss et al., 1982; Kalish et al., 1983; Freedman et al., 1966). Antituberculous $\operatorname{IgA}$ activity was almost undetectable, and IgM activity was far less discriminatory than that of IgG. To reduce IgM interference, samples were diluted in dithio threitol before testing, and the tracer used in the assay was anti-IgG. The most suitable dilution for testing samples was 1 in 40 , determined from the sigmoidal regressions of 42 titrated samples. Similar optimum dilution levels have been described in other ELISA tests for tuberculosis (Reggiardo et al., 1980; Straus and Wu, 1980; Benjamin and Daniel, 1982; Stroebel et al., 1982).

The overall sensitivity of the assay was $94 \%$ but with untreated cases was only $82.5 \%$. These figures compare favourably with results of other studies with different antigens (Nassau et al., 1976; Grange et al., 1980; Reggiardo et al., 1980; Daniel et al., 1981; Reggiardo et al., 1981; Stroebel et al., 1982; Ziess et al., 1982; Benjamin et al., 1984). We conclude from the consistent sensitivity figures of these serodiagnostic tests that tuberculosis evokes a specific humoral response against a wide range of antigens, but a proportion of patients, estimated to be c. $20 \%$, fail to produce specific antibodies at a significantly high level before therapy. Because of these patients, sensitivity of a test for active disease becomes low.

In the present study, most of the patients whose sera were non-reactive in the test had far-advanced pulmonary tuberculosis with heavy infections and smear-positive sputa. This group did not present problems in clinical diagnosis. In contrast, microscopy-negative, culture-positive cases had a high antibody activity. A possible explanation for this observation may be related to pathogenesis. Constant release of organisms or antigens from the site of infection may lead to (i) chronic stimulation of antibody synthesis resulting in progressive production of low avidity antibody, and (ii) formation of circulating immune complexes of the more reactive antibodies with the released antigen resulting in a considerable reduction of detectable antibody. This hypothesis is consistent with two observations: (i) tuberculosis causes an increase in the overall con- centrations of circulating IgG and IgA (Faulkner et al., 1967; Nash, 1979; Skvor et al., 1979), not reflected in the specific antibody as measured by ELISA with mycobacterial antigens (Kaplan and Chase, 1980; Krambovitis, 1985); and (ii) the presence of circulating immune complexes has been demonstrated (Carr et al., 1980; Johnson et al., 1981) and there is an inverse relationship between the concentration of immune complexes and antimycobacterial antibody (Carr et al., 1980). An alternative explanation which has been proposed is the existence of an immunologic spectrum (Daniel et al., 1981). This concept suggests that at one extreme of the spectrum tuberculosis is localised to confined foci with well developed cell-mediated immunity (CMI) but little or no detectable antibody; and at the other end of the scale there is disseminated disease with poor CMI but with high antibody levels (Daniel, 1980). The present study demonstrated the existence of a wide pathogenic and immunologic spectrum but no clear distinction between antibody and delayed hypersensitivity, which is an index of CMI. The mean antibody activity of the tuberculin-anergic group was slightly higher than that of the tuberculin-highly reactive group. Neither was there any correlation between extent of disease and antibody, although antibody activity was marginally higher in far-advanced cases.

Chemotherapy was associated with increased antibody activity as shown by groups of patients treated for approximately the same period of time. Similar responses have been reported in tests with different mycobacterial antigens (Janicki et al., 1971; Kaplan and Chase, 1980; Daniel et al., 1981) and these may be associated with increasing levels of antigen release as suggested by Kaplan and Chase (1980).

Antibody activity of control subjects from the high prevalence area was higher than that of the European controls, and sera from the high prevalence area gave a false-positive rate of $15 \%$. Similar results were reported by Benjamin and Daniel (1982) who used a cytoplasmic protein as antigen. Several reasons for false-positive reactions have been suggested (Grange, 1984) but in the present study the higher probability of exposure to infection was considered to be the main factor for these results. No attempt was made to exclude active tuberculosis by accepted criteria when the samples were taken and infection cannot be excluded.

Vaccination with BCG did not elevate antibody activity in seven adults studied. Similar results have been reported with routine BCG vaccinations (Fusillo and Weiss, 1958; Kalish et al., 1983) 
although large doses or repeated injections of BCG for treatment of neoplastic disease can induce a high antibody response at least in other test systems (Wile et al., 1977; Kaplan et al., 1980; Winters and Lamm, 1981).

The results of the present study demonstrated a spectrum of humoral responses in active tuberculosis which did not depend on the clinical status of the patient. As the overall positive and negative predictive values were $94 \%$ and $85 \%$, respectively, with samples from a high prevalence area, the assay may

\section{REFERENCES}

Benjamin R G, Daniel T M 1982 Serodiagnosis of tuberculosis using the enzyme-linked immunosorbent assay (ELISA) of antibody to Mycobacterium tuberculosis antigen 5. American Review of Respiratory Diseases 126:1013-1016.

Benjamin R G, Debanne S M, Ma Y, Daniel T M 1984 Evaluation of mycobacterial antigens in an enzyme-linked immunosorbent assay (ELISA) for the serodiagnosis of tuberculosis. Journal of Medical Microbiology 18:309-318.

Carr R I et al. 1980 Immune complexes and antibodies to BCG in sera from patients with mycobacterial infections. Clinical and Experimental Immunology 39:562-569.

Daniel T M 1980 The immunology of tuberculosis. Clinics in Chest Medicine 1:189-201.

Daniel T M, Oxtoby M J, Pinto E, Moreno E 1981 The immune spectrum in patients with pulmonary tuberculosis. American Review of Respiratory Diseases 123:556-559.

Daniel T M, Van Der Kuyp F, Anderson P A 1981 Initial clinical trial of Mycobacterium tuberculosis antigen 5 in tuberculinpositive human subjects. American Review of Respiratory Diseases 123:517-520.

Duncan R J S, Weston P D, Wriggleswoth R 1983 A new reagent which may be used to introduce sulfydryl groups into proteins and its use in the preparation of conjugates for immunoassay. Analytical Biochemistry 132:68-73.

Ellens D J, Gielkens A L J 1980 A simple method for the purification of 5-aminosalicylic acid. Application of the product as substrate in enzyme-linked immunosorbent assay (ELISA). Journal of Immunological Methods 37:325332.

Faulkner J B, Carpenter R L, Patnode R A 1967 Serum protein and immunoglobulin levels in tuberculosis. American Journal of Clinical Pathology 48:556-560.

Freedman S O, Dolovich J, Turcotte R, Sault F 1966 Circulating IgG (7S) hemagglutinins in pulmonary tuberculosis. American Review of Respiratory Diseases 94:896-904.

Fusillo M H, Weiss D L 1958 Lack of circulating antibodies after BCG immunization as assayed by the globulin titration technique. American Review of Tuberculosis and Pulmonary Diseases 78:793.

Grange J M 1984 The humoral immune response in tuberculosis: its nature, biological role and diagnostic usefulness. Advances in Tuberculosis Research 21:1-78.

Grange J M, Gibson J, Nassau E, Kardjito T 1980 Enzymelinked immunosorbent assay (ELISA): a study of antibodies to Mycobacterium tuberculosis in the $\operatorname{IgG}, \operatorname{IgA}$ and $\operatorname{IgM}$ classes in tuberculosis, sarcoidosis and Crohn's disease. Tubercle 2980, 61, 145-152.

Janicki B W, Goldstein R A, Aron S A 1971 Immunoelectro- have applications in the serodiagnosis of tuberculosis. The results of such a test, however, must be interpreted with supporting evidence from other accepted criteria.

I thank Dr Kleeberg and Mrs Depten of the TB Research Institute, Pretoria, South Africa for providing samples of serum from patients and clinical information, Mr. Peche of Wellcome Diagnostics (South Africa) Ltd for organising the collection of samples and case histories, and Mrs P. Thurbin for typing the manuscript. phoretic studies of the precipitating antibody response in tuberculosis (letter). American Review of Respiratory Diseases 103:894.

Johnson N L, McNicol M W, Burton-Kee E J, Mowbray J F 1981 Circulating immune complexes in tuberculosis. Thorax 36:610-617.

Kalish S B, Radin R C, Phair J P, Levitz D, Zeiss C R, Metzger E 1983 Use of an enzyme-linked immunosorbent assay technique in the differential diagnosis of active pulmonary tuberculosis in humans. Journal of Infectious Diseases 147:523-530.

Kaplan M H, Armstrong D, Pinsky C 1980 Antibody responses to mycobacterial antigens in patients immunized with $B C G$ for the treatment of neoplastic disease. Cancer 46:21952202.

Kaplan M H, Chase M W 1980 Antibodies to mycobacteria in human tuberculosis. I. Development of antibodies before and after antimicrobial therapy. Journal of Infectious Diseases 142:825-834.

Kapp O H, Vinogradov S N 1978 Removal of sodium dodecyl sulfate from proteins. Analytical Biochemistry 91:230-235.

Krambovitis E 1985 An investigation of immunodiagnostic methods for tuberculosis in humans. Ph.D. thesis, University of London, p 142.

Krambovitis E, Mclllmurray M B, Lock P E, Hendrickse W, Holzel H 1984 Rapid diagnosis of tuberculous meningitis by latex particle agglutination. Lancet 3:1229-1231.

Mackaness G B 1954 The growth of tubercle bacilli in monocytes from normal and vaccinated rabbits. American Review of Tuberculosis and Pulmonary Diseases 69:495-504.

Malvano R, Boniolo A, Dovis M, Zannino M 1982 ELISA for antibody measurement aspects related to data expression. Journal of Immunological Methods 49:51-60.

Nash D R 1979 Serum immunoglobulin abnormalities in patients with respiratory tract disease. Annals of Clinical Research 11:49-52.

Nassau E, Parsons E R, Johnson G D 1976 The detection of antibodies to Mycobacterium tuberculosis by microplate enzyme-linked immunosorbent assay (ELISA). Tubercle 57:67-70.

Reggiardo Z, Aber V R, Mitchison D A, Devi S 1981 Hemagglutination tests for tuberculosis with mycobacterial glycolipid antigens. Results in patients with active pulmonary tuberculosis before and during chemotherapy and in healthy tuberculosis contacts. American Review of Respiratory Diseases 124:21-25.

Reggiardo Z, Middlebrook G 1974 Failure of passive serum transfer of immunity against aerogenic tuberculosis in rabbits. Proceedings of the Society of Experimental Biology and Medicine 145:173-175. 
Reggiardo Z, Vazquez E, Schnaper L 1980 ELISA tests for antibodies against mycobacterial glycolipids. Journal of Immunological Methods 34:55-60.

Skvor J, Trnka L, Kugukovova Z 1979 Immunoprofile studies in patients with pulmonary tuberculosis. II. Correlation of levels of difference classes of immunoglobulins and specific antibodies with the extent of tuberculosis. Scandinavian Journal of Respiratory Diseases 60:168-171.

Straus E, Wu N 1980 Radioimmunoassay of tuberculoprotein derived from Mycobacterium tuberculosis. Proceedings of the National Academy of Sciences of the USA 77:4301-4304.

Stroebel A B, Daniel T M, Lau J H K, Leong J C Y, Richardson H 1982 Serologic diagnosis of bone and joint tuberculosis by an enzyme-linked immunosorbent assay. Journal of Infectious Diseases 146:280-283.
Suter E 1956 Interaction between phagocytes and pathogenic microorganisms. Bacteriological Reviews 20:94-132.

Wile A G, Sparks F C, Morton D L 1977 Monitoring immunotherapy with bacillus Calmette-Guérin by antibody titer. Cancer Research 37:2251-2256.

Winters W D, Lamm D L 1981 Antibody response to bacillus Calmette-Guérin during immunotherapy in bladder cancer patients. Cancer Research 41:2672-2676.

Zeiss C R, Radin R C, Williams J E Levitz D, Phair J P 1982 Detection of immnoglobulin $G$ antibody to purified protein derivative in patients with tuberculosis by radioimmunoassay and enzyme-linked immunosorbent assay. Journal of Clinical Microbiology 15:93-96. 